\title{
«Enemies of human beings»: Josep Ferrater Mora on blood fiestas
}

\author{
Andrew Linzey \\ The Ferrater Mora Oxford Centre for Animal Ethics \\ University of Oxford \\ andrewlinzey@aol.co
}

\begin{abstract}
Ferrater Mora maintained that «an enemy of animals is another way of being an enemy of human beings», and similarly many famous thinkers from Aquinas to Kant have held that cruelty to animals leads to cruelty to humans. But how precisely are we to understand this connection? This paper reviews the work of Brian Klug, Thomas I. White, Jonathan Edwards, and James Gustafson, and suggests that cruelty to animals should be rightly characterised as a "degradation» arising from multidimensional deficiency: (i) a failure of perception, resulting in (ii) an enfeebled intellect, and (iii) a contracted, shrivelled sensitivity. If true, animal abuse should be taken with greater seriousness by moralists, if only because there is an ineradicable human interest in curbing our degradation of animals. Indeed, there is now mounting medical, psychological, and statistical evidence of the link between animal cruelty and human anti-social behaviour.
\end{abstract}

Key words: animal ethics, animal experimentation, animal rights, blood fiestas, cruelty, desensitisation, empathy, hunting, perception, sinfulness, sensitivity, species, the fall.

\section{Resum. «Enemics dels éssers humans»: Josep Ferrater Mora sobre les festes cruels}

Ferrater Mora afirmava que ser «un enemic dels animals és una altra manera de ser un enemic dels éssers humans», així com molts pensadors il.lustres des de Tomàs d'Aquino fins a Kant han sostingut que la crueltat envers els animals condueix a la crueltat envers els humans. Però, com hem d'entendre exactament aquesta connexió? Aquest article examina l'obra de Brian Klug, Thomas I. White, Jonathan Edwards i James Gustafson, i suggereix que la crueltat envers els animals s'hauria de caracteritzar pròpiament com una «degradació» que emergeix d'una deficiència multidimensional: (i) un error de percepció, que produeix (ii) un intel-lecte feble, i (iii) una sensibilitat reduïda i esmorteïda. Si això fos cert, el maltractament dels animals hauria de ser considerat amb molta serietat pels moralistes, encara que només fos perquè hi ha un interès humà irrenunciable a posar fi a la nostra degradació dels animals. De fet, hi ha actualment una enorme evidència mèdica, psicològica i estadística del vincle entre la crueltat cap als animals i un comportament humà antisocial.

Paraules clau: ètica dels animals, experimentació amb animals, drets dels animals, festes cruels, crueltat, desensibilització, empatia, caça, percepció, maldat, sensibilitat, espècies, la caiguda. 
In an essay entitled Pockets of Cruelty ${ }^{1}$ on the so-called fiestas that take place in some Spanish villages, Josep Ferrater Mora starts off by telling his readers that he was in Spain in August of 1990 because he was participating in a Summer School course given by the Complutense University of Madrid. He relates how one morning when he was reading the newspapers, two articles caught his attention: one was entitled Barbaric Fiesta and was written by Manuel Leguineche and the other was entitled Spain, the worst enemy of animals by Carmen del Caño. He believed, he said, that the articles were fictitious and expresses his admiration and astonishment that these authors could have imagined such cruel and fantastic scenes.

Ferrater Mora then tell us that he was mistaken in supposing that these two journalists were displaying their creative and imaginative abilities for he had seen a video taken of some of the so-called «blood fiestas» that the authors describe. One fiesta involved shows how a crowd of people drag a goat up to the high bell tower of a church and then push her off so that she lands wounded and dying on the ground. Ferrater Mora describes the people acting "with an abandon of a real Bacchanalia», entertaining themselves «in the tortuous death of the pitiful creature» ${ }^{2}$.

A second fiesta involved a bull who has a flaming substance attached to his horns so that the animal «runs from one place to another, terrified, frantically trying to rid itself of these hellish flames which crackle on both sides of his head». The participants in this gruesome event slap and hit the animal amidst shouts «of the approving crowd $»^{3}$.

The people seen in the video act as if the animals involved in these cruel events were nothing more than an animal in a Walt Disney cartoon that could be squashed, trampled or run over so that nothing more remains than a flat substance that can later push and pull itself back into its original shape and marvelously return to life. But it is impossible to think that they really believed that for there would be no fun, no excitement in throwing a cardboard goat from a church tower, no excitement in watching a non-sentient entity crash to the ground. Terrible to say, but it seems that these people were aroused to a fever pitch of excitement because they wanted to participate in the suffering of a creature, precisely one that could experience pain and terror, and they wanted to watch the slowly dying animal.

Do such activities produce a surge of adrenalin and a feeling of excitement and pleasure? Max Lerner, an American sociologist, balefully suggests that «Every people, no matter how civilized, must have the chance to yell for blood» ${ }^{4}$.

1. Ferrater Mora, Josep (1994). «Bolsas de crueldad» («Pockets of Cruelty») [1990]. Mariposas y supercuerdas: Diccionario para nuestro tiempo [hereafter FERRATER MORA. «Pockets»]. Barcelona: Península, p. 139-140, published posthumously, trans. by P. Cohn.

2. Ferrater Mora. «Pockets», p. 139.

3. Ferrater Mora. «Pockets», p. 139.

4. Lerner, Max (1957). America as a Civilization. New York: Simon \& Shuster, p. 812. 
Does this explain, for example, so-called «buck fever» experienced by some hunters when, gun in hand, they see a deer and are filled with excitement, with heart pounding and often a shaking hand? And are not these examples of pathology? What Ferrater Mora describes as «degradation»?

Near the end of Ferrater Mora's article he says that he was made aware of the suffering of animals by another, but that he himself realizes that «an enemy of animals is another way of being an enemy of human beings» ${ }^{5}$. He does not bother to explain this comment. Did he suppose that his meaning was so clear that he need not say more?

To be classified as an "enemy» is one of the most pejorative of all human descriptions. An enemy is by definition a hostile person, a member of an opposing party or camp. Moreover, it is difficult to believe that Ferrater Mora did not appreciate the historical resonance that this expression would have in a country that itself had suffered civil war and had, for many long years, experienced dictatorship. And what — in that context - is the distinguishing mark of an enemy? Perhaps this most of all: that they betray their own side. Thus to be an enemy of the people is a way of designating someone as a traitor to the cause they should represent.

But how is it precisely that cruelty to animals betrays human beings or, more precisely, their very humanity?

\section{II}

Ferrater Mora may have had in mind the great thinkers of the past who have variously linked abuse of animals to human violence. For instance, St Thomas Aquinas echoes the theme that cruelty to animals may lead to cruelty to humans. He writes:

Indeed, if any statements are found in Sacred Scripture prohibiting the commission of an act of cruelty against brute animals, for instance, that one should not kill a bird accompanied by her young (Deut., XXII, 6), this is said [...] to turn the mind of man away from cruelty which might be used on other men, lest a person through practicing cruelty on brutes might go on to do the same to $\operatorname{men}^{6} \ldots$

St. Thomas More writes that the Utopians

[.... think this enjoyment in beholding deaths, even in beasts, comes from an inherently cruel disposition or from the habitual practice of cruelty in so brutal a pleasure ${ }^{7}$.

Montaigne in his essay Of Cruelty declares that

5. Ferrater Mora. «Pockets», p. 141.

6. ST. Thomas Aquinas. Summa Contra Gentiles, III, 2, 112:13.

7. More, St. Thomas (1949). Utopia. Book II, trans. and edited by H. V. S. Ogden. New York: Appleton-Century-Crofts, p. 51. 
Natures that are bloodthirsty toward animals give proof of a natural propensity toward cruelty. At Rome, after they became accustomed to the spectacle of the slaughter of animals, they proceeded to that of men and of gladiators ${ }^{8}$.

Locke also echoes the very same idea:

the custom of tormenting and killing of beasts will, by degrees, harden their minds even towards men; and they who delight in the suffering and destruction of inferior creatures, will not be apt to be very compassionate or benign to those of their own kind. Our practice takes notice of this, in the exclusion of butchers from juries of life and death'.

Kant says much the same thing in his Lectures on Ethics. Kant claims that "[....] we have duties towards the animals because thus we cultivate the corresponding duties towards human beings», asseting that "Tender feelings towards dumb animals develop humane feelings towards mankind». He gives as an example a man who shoots his dog because the dog is too old to serve. Such an act, says Kant,

is inhuman and damages in himself that humanity which it is his duty to show towards mankind. If he is not to stifle his human feelings, he must practice kindness towards animals, for he who is cruel to animals becomes hard also in his dealings with $\operatorname{men}^{10}$.

Kant emphasizes his point by discussing Hogarth's engravings entitled The Stages of Cruelty (1751):

He [Hogarth] shows how cruelty grows and develops. He shows the child's cruelty to animals, pinching the tail of a dog or a cat; he then depicts the grown man in his cart running over a child, and lastly the culmination of cruelty in murder. He thus brings home to us in a terrible fashion the rewards of cruelty [...] [Kant continues that,] In England butchers and doctors do not sit on a jury because they are accustomed to the sight of death and hardened ${ }^{11}$.

Although both Kant and Locke use as proof of their ideas that butchers were not allowed to sit on juries in England, the notion that cruelty to animals leads to cruelty to humans is an intuition shared by these thinkers, but it is not an established fact.

8. Montaigne, Michel de (1960). "Of Cruelty" [1578-1580]. The Complete Essays of Montaigne, II, trans. by Donald M. Frame. New York: Garden City, p. 109.

9. LOCKE, John (1801). "Cruelty». "Some Thoughts Concerning Education» [1693]. In: Works of John Locke in Ten Volumes, $10^{\text {th }}$ ed. London, p. 112; extract in LINZEY, Andrew and Clarke, Paul A. B. (eds.) (2004). Animal Rights: A Historical Anthology. New York: Columbia University Press, p. 119.

10. KANT, Immanuel (1963). «Duties towards animals and spirits» [Lectures on Ethics, 17751780], trans. Louis INFIELD. Indianapolis and Cambridge: Hackett Publishing Company, p. 240 .

11. KANT. «Duties towards animals and spirits», p. $240 \mathrm{f}$. 


\section{III}

That human beings are somehow diminished by inflicting cruelty upon animals; even to the extent of putting themselves (and other humans) at risk is thus often assumed. But, if true, how does this happen precisely?

The first issue I want to call attention to concerns perception, or rather our lack of it. In a little known essay by Brian Klug entitled: "Can we see a moral question about animals?» ${ }^{12}$ he uses Thoreau's notion of «the intention of the eye», to call attention to how some scientists fails to see a moral issue in animal experimentation. He writes of how there is «a certain kind of tunnel vision [in science] which subverts the question altogether, preventing it from being seen for what it is: a moral question about animals» ${ }^{13}$. He gives the example of Doctor Moreau in H. G. Wells' famous novel, whose research involves turning animals into humanoid creatures. The Doctor explains his life's work, thus:

You cannot imagine the strange colourless delight of these intellectual desires. The thing before you is no longer an animal, a fellow-creature, but a problem. Sympathetic pain —all I know of it I remember as a thing I used to suffer from years ago. I wanted - it was the only thing I wanted- to find out the extreme plasticity in a living shape ${ }^{14}$.

Klug takes up the notion that «sympathetic pain» is something one suffers from - like a weakness or an affliction. Moreau appears to believe that as an «investigator» ordinary human emotions should not apply to him. He is not concerned with these things — or rather he is above them. Moreau speaks of «remorselessness» - a state beyond feeling. But Klug argues that there is always «logical space for the moral question», which does not simply involve following expert opinion. "Experts are never merely experts; they are, in the first place human beings», says Klug. "Calling a question moral is to call attention to this fact: to the fact that we are human beings first, whatever the particular angle of our professional interest» ${ }^{15}$.

The implication in Klug's article is not only that we fail to see a moral question about animals when we treat them as laboratory tools, but also that we have lost something of ourselves — our very humanity — in doing so. By failing to perceive correctly what is before us, we impoverish both the object (or subject) seen, and also ourselves. We might say that the lens through which

12. KLUG, Brian (1998). «Can we see a moral question about animals?». In: LINZEY, Andrew and Yамамото, Dorothy (eds.) (1998). Animals on the Agenda: Questions about Animals for Theology and Ethics [Hereafter: KLUG. "Can we see»]. London: SCM Press; Chicago: University of Illinois Press, p. 206-215.

13. KLUG. "Can we see», p. 206; original emphases. The work from H. D. THOREAU (1975) is "Autumnal Tints». The Selected Works of Thoreau, edited by W. Harding. Boston, MA: Houghton Mifflin, p. 709.

14. WeLLS, H. G. (1993). The Island of Doctor Moreau [hereafter: Wells. Moreau]. London: Everyman, 1993, p. 73; KLUG. "Can we see», p. 207.

15. KLUG. «Can we see», p. 212. 
we see animals diminishes both the viewer and the viewed. The result is illustrated in Moreau's revealing line that: "The thing before you is no longer an animal, a fellow-creature, but a problem» ${ }^{16}$. What could have been a fellowcreature with whom we have a respectful, even convivial relationship, is turned into a «thing».

Now, if this analysis is correct, it follows that those whose sight is so affected that they regard other sentient beings as "things", suffer from a kind of diminishment that warps ordinary human sensitivity. It isn't that they are «bad» people as such, but it is true that they are impaired. And what is true of the scientific investigator must also be true of those involved in blood fiestas. The goat or bull is not perceived as a «fellow-creature» but a «thing», and hence can be used and abused. We might say that the participants' moral sight has been dimmed and their emotional responses are subsequently disordered. For that reason alone, the enemies of animals can be said to be the enemies of human beings.

All this, incidentally, chimes in with what is a common reaction to images or photographs of animal cruelty. "I can't bear to see these things» many say. "They are just too upsetting» add others. It is not difficult to understand these reactions. Pictures of cruelty to animals are indeed harrowing and quite appropriately engender an emotional response. But there is also a less positive interpretation, and one that might apply in at least some cases, and which may go to the heart of the matter. It is that we would rather not see at all - that the act of seeing fully and properly - is simply too upsetting in that it requires us to give space to that moral question of which Klug spoke, and thus enlarge our moral universe.

\section{IV}

In order to illuminate the matter further, I want to draw, secondly, on an article by Thomas I. White entitled: «Dolphin drive hunts and the Socratic dictum: 'vice harms the doer' ${ }^{17}$. White's article is a critique of hunting dolphins but, unlike most critiques, centres on how such hunting harms the human beings involved. He utilises Socrates' dialogue found in the Gorgias and specifically the dialogue between Socrates and Callicles ${ }^{18}$. Callicles is an intelligent young Athenian who is ambitious but ruthless. Socrates says that he is a slave to his desires: «the two current loves of his life —one a beautiful young man, the other, the Athenian public» and that Callicles will say anything to please them ${ }^{19}$. Socrates' indictment runs as follows:

16. Wells. Moreau, p. 73; KLUG. "Can we see», p. 207.

17. White, Thomas I. (2009). "Dolphin drive hunts and the Socratic dictum: "Vice harms the doer" " [hereafter: WhITE. "Vice harms the doer»]. In: LinZEY, A. (ed.) (2009). The Link Between Animal Abuse and Human Violence, Brighton (UK) and Portland (USA): Sussex Academic Press, p. 329-340

18. Plato. Gorgias, trans. by W. C. Helmbold (Indianapolis, IN: Bobbs-Merrill, 1962); WHITE. "Vice harms the doer», p. 331 and 340.

19. WHiTE. «Vice harms the doer». 
Now I have noticed that in each instance, whatever your favourite says, however his opinions may go, for all your cleverness you are unable to contradict him, but constantly shift back and forth at his whim. If you are making a speech in the Assembly and the Athenian public disagrees, you change and say what it desires; and in the presence of the beautiful son of Pyrilampes your experience is precisely similar. You are unable to resist the plans or the assertions of your favourite; and the result of this is that if anyone were to express surprise at what you say on various occasions under the influence of your loves, you would tell him, if you wanted to speak true, that unless your favourites can be prevented from speaking as they do, neither can you ${ }^{20}$.

In other words, Callicles is so driven by his desires (to secure the approbation of the one he loves or to gain popularity) that he has an enfeebled intellect as a result: his words are «now aligned with his search for pleasure and not with his reason and search for truth ${ }^{21}$. Desire has hampered the development of a truly independent mind.

White finds further confirmation of this contention in two directions. The first is St Augustine's view that vice leads to ignorance and further incapacity to do good. It is a kind of self-inflicted punishment that «the man who does not act rightly although he knows what he ought to do, [henceforth] loses the power to know what is right; and whoever is unwilling to do right when he can, loses the power to do it when he wills to» ${ }^{22}$. According to Socrates and Augustine, wrongdoing weakens the intellect and helps destroy moral resolve.

The second is found in the work of psychologist Abraham Maslow. White cites Maslow's work on psychological health which linked «self-actualisation» to a strong moral sense:

at least in the group that I studied they [self-actualised individuals] tended to agree about what was right and wrong, as if they were perceiving something real and extrahuman rather than comparing tastes that might be relative to the individual person ${ }^{23}$.

Thus it seems that, in this case at least, «agreement on values proceed[ed] from their superior ability to perceive reality» ${ }^{24}$. Maslow provides this example:

This is very much like the situation with a surgeon or dentist. The surgeon opening up the abdomen and finding an inflamed appendix knows that it had better be cut out because if it bursts it will kill the person. This is an example of truth dictating what must be done, of the is dictating the ought ${ }^{25}$.

20. Plato. Gorgias, p. 49-50, 481d-482a; White. "Vice harms the doer».

21. White. «Vice harms the doer», p. 332.

22. St. Augustine (1964). On Free Choice of the Will, trans. by Anna S. Benjamin and L. H. HACKSTAFF. Indianapolis, IN: Bobbs-Merrill, p. 128; WHITE. «Vice harms the doer», p. 333.

23. Maslow, A. H. (1971). The Farther Reaches of Human Nature [hereafter: MasLOW. Farther Reaches]. New York: Penguin Books, p. 9; WHITE. «Vice harms the doer», p. 334.

24. White. «Vice harms the doer», p. 334.

25. MASLOW. Farther Reaches, p. 117; WHITE. "Vice harms the doer», p. 334; original emphasis. 
Maslow makes the distinction between the «average» person who may be described as «is-perceptive but ought-blind» and the healthy person as "more ought-perceptive». Although Maslow does not explicitly say that «vice harms the doer", White suggests that "his ideas imply that vice is a trait of the emotionally unhealthy, and that such individuals lack the superior cognitive abilities of the self-actualised». Specifically that

One of the traits of the "ought-blind», then, is that looking at the same facts as the "ought-perceptive» and coming to a faulty conclusion about the ethical character of the actions in question ${ }^{26}$.

White maintains that the thesis of vice harming the doer can be most readily shown in the weak and incoherent arguments presented (in his case) for the hunting of dolphins. Apart from faulty factual claims, disregard of scientific evidence and logical fallacies, he finds that defenders of hunting discount ethical considerations on the grounds that they are «irrelevant» or "ethnocentric», and dismiss claims of «cruelty» as "wholly subjective»" ${ }^{27}$. It is of course this rejection of the ethical dimension to our treatment of animals that so characterises the arguments of those who wish to harm them.

In short, White finds support in Socrates dictum - a position echoed in Augustine and Maslow - that «the consequence of vice is that a desire for something grows so strong that satisfying it is more important than perceiving reality accurately, dealing with uncomfortable truths about a situation and respecting the canons of logic» ${ }^{28}$. When it comes to dolphin hunts, ignoring evidence and argument as hunters do «must surely count as serious harm to one's intellect», the sort that Socrates "would predict from unethical actions» ${ }^{29}$.

\section{V}

My third source of illumination comes from theologian James M. Gustafson in his work Theology and Ethics ${ }^{30}$. In seeking to provide a metaphor that might best explain the meaning of the traditional doctrine of sin, Gustafson turns to St. Augustine and his notion that the "fall» consisted of a "contraction» of the human spirit. He cites Augustine that «man did not fall away to become nothing; but being turned towards himself, his being became more contracted than it was when he clave to Him who supremely is» ${ }^{31}$. And then Gustafson connects with the development of this thought in the work of Jonathan Edwards. The piece is so rich - and so relevant from our perspective - that it needs to be quoted in full:

26. WHITE. «Vice harms the doer», 334; original emphasis.

27. WHITE. «Vice harms the doer», p. 337.

28. WhiTE. «Vice harms the doer», p. 337.

29. White. «Vice harms the doer», p. 337.

30. Gustafson, James M. (1981). Theology and Ethics [hereafter: GuSTAFSON. Theology and Ethics]. Oxford: Blackwell.

31. St. Augustine. City of God, Book 14, 13, p. 460; Gustafson. Theology and Ethics, p. 304. 
Immediately upon the fall, the mind of man shrank from its primitive greatness and expandedness, to an exceeding smallness and contractedness ... Before, his soul was under the government of that noble principle of divine love, whereby it was enlarged to the comprehension of all his fellow-creatures and their welfare. And not only so, but it was not confined within such narrow limits as the bounds of creation, but went forth in the exercise of holy love to the Creator, and abroad upon the infinite ocean of good, and was, as it were, swallowed up by it, and became one with it. [With the fall] all this excellent enlargedness of man's soul was gone, and thenceforth he himself shrank, as it were, into a little space, circumscribed and closely shut up within itself, to the exclusion of all things else. Sin, like a powerful astringent, contracted his soul to the very small dimensions of selfishness; and God was forsaken, and fellowcreatures forsaken, and man retired within himself, and became totally governed by narrow and selfish feelings and principles ${ }^{32}$.

To appreciate the argument here one does not have to subscribe to the fall as a historical event. Rather what is significant is the truth of the anthropological depiction of a species tragically caught up in a web of its own self-centredness. Although Edwards did not intend (as far as I know) a trans-species meaning to the words "fellow-creatures», it is surely not invalid to view his thought in that wider perspective. As Gustafson himself writes: «The metaphor of contraction can refer not only to individual persons but to particular human communities, from the intimacy of the family to the breadth of a nation-state; it can even refer to the species as a whole» ${ }^{33}$.

Applying this analogy, then, a lack of sensitivity to other creatures can be seen as itself a mark of human sinfulness - a sign of the alienation of the species from itself and of the radical incompleteness of humanity. Selfishness works like a "powerful astringent» as Edwards characterises it —reducing our capacity for sympathy beyond ourselves. And if that is true, it also follows that species self-preoccupation is a telling indication of an essentially wayward humanity alienated from itself.

\section{VI}

I now want to pick up that notion of «degradation» to which Ferrater Mora refers in his depiction of fiestas:

Apparently horrors are diverting and, as one can see in the video [of the bull with flaming horns], all the more so as the animal nears the end of her, or as the case may be his, debasement. This must be a fiesta of degradation for the benefit of I don't know which vindictive gods. But no, there are no gods here; only the pure, naked fury of human beings ${ }^{34}$.

32. EDWARDS, Jonathan (1834). «Charity». In: The Works of Jonathan Edwards, 2 vols. (Worcester, MA: 1834; reprinted Edinburgh: The Banner of Truth Trust, 1974), p. 157-58; GUSTAFSON. Theology and Ethics, p. 304-5.

33. Gustafson. Theology and Ethics, p. 305.

34. Ferrater Mora. «Pockets», p. 140. 
Who or what is being degraded? Are animals degraded by fiestas? Obviously so. Their being and nature is treated with contempt, their suffering is callously disregarded and turned into a public spectacle. But are not humans also degraded? It seems inescapable that such degradation is one in which humans also degrade themselves.

The issue is how to meaningfully characterise that degradation. My analysis suggests that there are at least three ways. To «degrade» means by definition to diminish, reduce, or down play something essential or authentic. In that precise sense, our degradation may be characterised as consisting in:

(i) a failure of perception, resulting in

(ii) an enfeebled intellect, and

(iii) a contracted, shrivelled sensitivity.

Let me provide an example that I have often used from my own experience that might illustrate the central issue.

The university where I used to work was situated amid acres of eighteenthcentury parkland. Wildlife abounded. From my study window I observed families of wild rabbits. Looking up from my word processor from time to time I gazed in wonder, awe, astonishment at these beautiful creatures. I sometimes said half-jokingly, «it is worth coming to the university for the rabbits». Occasionally I invited visitors to observe them. Some paused in conversation and said something like "Oh yes», as though I had pointed out the dust in my bookshelves or the colour of my carpet. What they saw was not rabbits. Perhaps they saw machines on four legs, "pests» that should be controlled, perhaps just other «things» 35 .

I trust I am labouring the obvious here. But this capacity for seeing - meaning being enthralled, awestruck, grasping the value of living beings outside ourselves is surely something central to living a fully human life. God's creation - or if you will, the complexity and interworking of the natural world - awed me, and should properly awe us all. Difficult though it is to believe, and terrible to say, it seems likely that, perhaps without realising it, some people have lost the capacity to perceive the value of other living creatures and in consequence live impoverished lives. Those who can see living creatures only as "things", and who cannot empathize with their death and suffering, have in fact cheated themselves, cut themselves off from a richness of experience and a joy in living. Their humanity, intellect, sensitivity and appreciation of the natural world have been so diminished that they are impaired.

Of course none of the foregoing proves such connections, but they do help us to understand more concretely than before how humans themselves are harmed when they treat other sentient creatures as «things». My judgement is 
that Ferrater Mora was obviously correct; such fiestas — and, by implication, all acts of cruelty to animals - exhibit a glaring human deficiency. An enemy of animals, even in the most benign sense — not as one who mistreats animals, but simply as one who simply does not see them as sentient individuals - is an enemy to himself, that is, to his own humanity. That deficiency is such that he is also an enemy to his fellow human beings, and to the wider community.

Certain things follow from this account. The first and most obvious is that the issue of animals, and how we treat them, deserves a great deal more attention that it currently receives. While it is true that philosophers have frequently written about animals and none of them more profusely than during the last 40 years $^{36}$, it is also the case that animals are still relegated to the margins of moral enquiry and regarded as a peripheral issue. This situation ought not to be allowed to continue. Impartial justice requires that the pains of animals are given much greater weight than they currently receive. Indeed, in terms of pain, suffering, deprivation and death, what we do to other sentient creatures constitutes one of the major moral issues of our time.

The second is that, if Ferrater Mora is right, there is an ineradicably human dimension to our treatment of animals. By that I mean that - apart from the issue of justice to individual sentients - there is a legitimate human interest in curbing our degrading treatment of animals. Of course our laws, conventions and customs frequently belie this fact; we have become so accustomed to maltreatment that we seldom credit it with the seriousness it deserves. Those who are cruel to animals are hardly ever dealt with severely by the courts or regarded as guilty of anti-human behaviour. What is needed is a much greater public recognition of why a world in which cruelty to animals goes unchecked is bound to be a less safe place for human beings. The issue of animal liberation is also about the liberation of human beings. The theologian Jürgen Moltmann rightly grasped this point in relation to the oppression of slaves and women, but it equally applies to our treatment of animals:

Oppression always has two sides: on the one hand, the master, on the other the slave; on the one hand the ruling man, on the other the serving woman. But oppressions of this kind destroy humanity on both sides ${ }^{37}$.

\section{VII}

The statement that an enemy of animals is another way of being an enemy of human beings may also be prescient. The article in which Ferrater Mora made this statement was published in 1994 , but the last decade has seen a number of studies published on the link between animal cruelty and human anti-social

36. For an excellent compendium of modern sources, see ARMSTRONG, Susan J. and BOTZLER, Richard G. (eds.) (2003). The Animal Ethics Reader, $2^{\text {nd }}$ edition. London and New York: Routledge.

37. Moltmann, Jürgen (2007). A Broad Place: An Autobiography, trans. by Margaret KoHL. London: SCM Press, p. 328. 
behaviour. Psychological, medical and statistical evidence is beginning steadily accumulate. In fact, the Centre bearing his name - the Ferrater Mora Oxford Centre for Animal Ethics - hosted a well-attended international conference on this very topic in $2007^{38}$. Paper after paper displayed the growing awareness that animal abuse is often a precursor, even sometimes a predictor, of subsequent abuse either to children, women or the aged. Many health care professionals now believe that viewing cruelty, or being engaged in cruelty to animals, leads to a stifling of one's sense of empathy and that, without these feelings, at least some people are more apt to engage in anti-social behaviour ${ }^{39}$. The Centre is the first in the world dedicated to pioneering ethical perspectives on animals through academic research, teaching and publication and thereby putting animals on the intellectual agenda. In the last century, Ferrater Mora was one of the first thinkers in Spain to raise the ethical issue of animals; we shall now ensure that he is not the last.

38. See http://www.oxfordanimalethics.com/index.php?p=conference_programme.

39. See, for example, some of the papers at the 2007 conference: BEETZ, Andrea M. «Empathy towards humans and animals as an indicator of emotional development»; FLYNN, Clifton P. "Beauty and the beasts: woman-battering, pet abuse, and human-animal relationships»; GULLONE, Eleonora. "The link between animal cruelty and human aggression across the lifespan»; HAWKSWORTH, Dawn and BALEN, Rachel. "Animal cruelty and child welfare: a health visitor's perspective», and RISLEY-CURTISS, Christina. "The role of animals in public child welfare practice», all in LINZEY, Andrew (ed.) (2009). The Link Between Animal Abuse and Human Violence. Brighton, UK, and Portland, USA: Sussex Academic Press, 2009. 